\title{
Penerapan Model Pembelajaran Daring berbasis WhatsApp dan Youtube untuk meningkatkan Partisipasi dan hasil belajar Mata pelajaran PAI siswa Sekolah Dasar
}

\author{
Raden Roro Vemmi Kesumadewi \\ STAI Al-Aqidah Al-Hasyimiyyah, Jakarta, Indonesia \\ E-mail: roro.vemmi79@gmail.com
}

\begin{abstract}
Article Info
Abstract

Article History

Received: 2021-07-12

Revised: 2021-08-15

Published: 2021-09-13

This study uses a qualitative descriptive method which aims to describe the activities of elementary school students in the learning process during the Pademi Covid-19 period. The research material is a PAI subject. The subjects in this study are elementary school teachers and students in order to obtain the expected research

Keywords: results related to the online learning process in the current pademic era. The data Learning; Online; collection technique uses triangulation, namely: observation, interviews and

Learning outcomes. documentation of the results of the work that has been written. From the findings, it shows that during the current Pademic, there are students who did not get material on the PAI learning process, the PAI learning process has many obstacles, both related to networks and quotas, students need to borrow cellphones so they could participate in learning and collect assignments, parents took part in helping the process of online learning. Learning PAI in the pandemic era, the teacher gives assignments by using the WhatsApp application and give examples of material by using YouTube. SBdP learning uses two offline and online learning methods.
\end{abstract}

\begin{tabular}{l}
\hline Artikel Info \\
\hline Sejarah Artikel \\
Diterima: 2021-07-12 \\
Direvisi: 2021-08-15 \\
Dipublikasi: 2021-09-13
\end{tabular}

Kata kunci:

Pembelajaran; Daring;

Hasil Belajar.

\begin{abstract}
Abstrak
Penelitian ini menggunakan metode deskritif kualitatif yang bertujuan untuk mendeskripsikan kegiatan siswa sekolah dasar dalam proses belajar dimasa pademi Covid-19. Bahan penelitian merupakan mata pelajaran PAI. Subjek dalam penelitian ini adalah guru serta siswa Sekolah Dasar di beberapa wilayah Tarumajaya Kbupaten Bekasi dan beberapa Sekolah Dasar di wilayah Kecamatan Tarumajaya guna mendapatkan hasil penelitian yang diharap terkait proses pembelajaran daring dimasa pademi saat ini. Teknik pengumpulan data menggunakan teknik triangulasi yaitu observasi, wawancara dan dokumentasi hasil pencapain karya yang telah ditulis. Dari hasil temuan bahwa pada masa pademi saat ini adapun siswa yang tidak mendapatkan materi pada pembelajaran PAI, Proses pembelajaran PAI memiliki banyak kendala baik terkait jaringan maupun kuota sehingga siswa perlu meminjam handphone agar dapat mengikuti pembelajaran dan mengumpulkan tugas, orang tua murid ikut andil membantu proses belajar secara daring, pembelajaran PAI dimasa pademi guru memberikan tugas dengan menggunakan aplikasi whatsaap dan memberikan contoh materi menggunakan youtube, pembelajaran PAI menggunakan dua metode pembelajaran manual dan online.
\end{abstract}

\section{PENDAHULUAN}

Terkait pembelajaran di lingkungan Sekolah Dasar merupakan langkah awal yang perlu diperhatikan sehingga anak tidak salah dalam mengikuti pembelajaran baik dalam sekolah misal tingah laku guru, kepala sekolah dan teman-temannya, adapun di lingkungan keluarga yaitu mempelajari pembelajaran yang diberikan oleh orangtua dan di lingkungan masyarakat misal tempat pergaulan anak dengan temantemanya. Hal ini akan mempengaruhi tingkah laku anak dimasa mendatang anak akan mudah menangkap apa yang ia lihat dan dengar lalu mencetaknya dalam wujud tingkah laku, kebiasaan dan hobbi, hal ini memiliki efek positif dan negatif untuk pertumbuhan anak. Menurut Moh. Suardi (2018: 8), tugas pokok seorang guru membelajarkan siswa. Masalah utama yang dihadapi dan perlu dipecahkan ialah apakah yang dapat dan harus dilaksanakan, selanjutnya bagaimana ia harus melakukannya. Sehubungan dengan itu, seorang guru perlu memahami dan menghayati kinerja belajar dan pembelajaran. Dalam hal ini guru berpegaruh besar untuk memberikan pembelajaran yang baik kepada siswanya, guru perlu memahami kondisi pada muridnya sehingga kegiatan belajar mengajar berjalan dengan baik sesuai dengan rencana awal. 
Belajar dapat dilaksanakan dimana pun dan kapan pun tidak harus selalu pada lingkungan formal yaitu sekolah saja, siswa seorang pelajar hendaknya tetap mengakui bahwa dirinya sebagai pelajar yang tetap harus belajar. Belajar dapat dilaksanakan di lingkungan sekolah, lingkungan rumah serta lingkungan bermain ataupun bergaul, belajar pun bisa dengan siapa saja dan di mana saja tidak ada batasanya terkecuali jika belajar pada hal yang negatif itu tidak perlu ditiru. Menurut Moh. Suardi (2018: 11), belajar merupakan perubahan dalam diri seseorang yang dapat dinyatakan dengan adanya penguasaan pola sambutan yang baru, berupa pemahaman, keterampilan dan sikap sebagai hasil proses hasil pengalaman yang dialami. Sedangkan belajar menurut Azhar Arsyad (2017: 1), belajar dalah suatu proses yang kompleks yang terjadi pada diri setiap orang sepanjang hidupnya, proses belajar itu terjadi karena adanya interaksi antara seseorang dengan lingkunganya. Pembelajaran dimasa pademi saat ini tentu semua yang berkaitan dengan pendidikan masih menggunakan sistem pembelajaran jarak jauh atau daring, hal ini pun telah disampaikan oleh Menteri Pendidikan bahwa pembelajaran pada masa pademi harus bersifat belajar menggunakan IT sehingga untuk mempermudah pembelajaran sehingga tidak perlu berjumpa atau tatap muka di kelas karena perlu adanya jaga jarak, sehingga mengurangi penyebaran virus Covid-19. Menurut Efendi (2020: 2), pembelajaran daring merupakan pembelajaran yang berlangsung di dalam jaringan dimana pengajar dan yang diajar tidak bertatap muka secara langsung.

Adapun jurnal yang ditulis oleh N.S.A. Lodo (2017:65) dalam tulisannya berjudul "Analisis Sikap dan Muatan Pembelajaran Sbdp Pada Tema Lingkungan Sahabat Kita Kurikulum 2013 Kelas V Serta Potensi Budaya Lokal Pendukung Dalam Pembelajaran". dalam tulisan N.S.A Lodo ditemukan bahwa dalam penelitianya mendeskripsikan nilai-nilai sikap dan nilai-nilai budaya lokal pendukungnya dalam Kurikulum 2013 tema Lingkungan Sahabat Kita Kelas V Sekolah Dasar. Subjek penelitian meliputi budayawan, guru PAI, guru PAI dan orang tua siswa. Hasil penelitiannya menunjukkan bahwa nilai-nilai sikap spiritual yang termuat adalah taat beribadah dan beprilaku syukur, nilai sikap sosial yang termuat yaitu jujur, disiplin, tanggung jawab, peduli dan percaya diri dan nilai-nilai budaya lokal yang muncul dalam aktivitas anak kelas tinggi yang mendukung pengembangan nilai-nilai sikap pada tema Bangga Sebagai Bangsa Indonesia yaitu, beberapa jenis permainan tradisional, cerita anak (satua), bernyanyi (magending), mengucapkan salam, dan kegiatan sembahyang (mebanten).

Selanjutnya jurnal yang telah diteliti oleh Arbaiyah Mareta Noer Chabiba, dengan judul penelitian "Integrasi Muatan Karakter Melalui Pembelajaran PAI di SD Plus AlMaimunTarumajaya-Bekasi". Penelitian ini bertujuan untuk mendeskripsikan perencanaan, pelaksanaan, evaluasi, faktor pendukung dan penghambat integrasi muatan karakter melalui pembelajaran PAI. Hasil menunjukkan perencanaan guru mempersiapkan PAI, pelaksanaan pendidikan karakter diimplementasikan dalam pembelajaran, kegiatan ekstrakulikuler dan kegiatan sehari-hari peserta didik, evaluasi dilakukan selama proses dan hasil karya seni, faktor pendukung integrasi muatan karakter yaitu adanya tenaga pendidik yang berkompeten, sarana prasarana yang memadai dan minat peserta didik pada PAI, faktor penghambat pendidikan karakter yaitu beberapa guru dan orang tua yang kurang berpartisipasi maksimal.

Jurnal selanjutnya melihat pada tulisan $\mathrm{Ni}$ Komang Suni Astini, dengan judul penelitian "Pemanfaatan Teknologi Informasi dalam Pembelajaran Tingkat Sekolah Dasar pada Masa Pandemi Covid-19". Dalam penelitiannya membahas manfaat dari teknologi informasi dalam proses pembelajaran di sekolah dasar pada masa pandemi Covid-19. Pembelajaran PAI mencangkup pembahasan yang berkaitan dengan seni, budaya dan prakarya. Menurut Sugiharto (2004) dalam Widia Pekerti (2018:4) bahwa seni merupakan fenomena yang kompleks. Batasan atau maknanya ditentukan oleh banyak faktor, seperti kurator, kritikus, pasar, pranata-pranata, paradigma akademis, kosmologi kultural, perubahan zaman aliran filsafat, dan sebagainya. terkait seni memiliki banyak faktor dan memiliki banyak pandangan sehingga tidak jarang orang dapat menyampaikan apa yang dimaksud dengan seni dan apa unsur pada seni. Sedangkan pengertian budaya diperkuat oleh Sarinah (2019:1), ilmu budaya dasar adalah ilmu yang mempelajari sebuah dasar-dasar kebudayaan, namun jika untuk mengingat terlalu sulit bisa diambil intinya saja agar tidak terlalu membebani pikiran otak. Budaya memang merupakan salah satu jiwa dari nilai-nilai yang ada di masyarakat. Jadi pengertian budaya adalah merupakan jalan atau arah didalam 
bertindak dan berpikir untuk memenuhi kebutuhan hidup baik jasmani maupun rohani.

Pembelajaran PAI merupakan pembelajaran yang unik dan berbeda dengan pembelajaran yang lain. Pembelajaran PAI memberikan pengetahuan yang baru kepada peserta didik sehingga hal ini akan membuat peserta didik merasa senang jika mengikuti pembelajaran PAI di kelas. Pembelajaran ini mempelajari seni tari, seni rupa dan prakarya serta mempelajari budaya Indonesia baik bahasa, rumah adat daerah, kostum rumah daerah serta mempelajari hal-hal yang berkaiatan dengan budaya lainnya. Tentu hal ini yang membuat siswa merasa senang mengikuti pembelajaran ini selain materi yang menyenangkan adapun kegiatan praktik sehingga pembelajaran tidak monoton. Menurut Ening Widaningsih (2020), Pendidikan Seni dan Budaya dan Keterampilan memiliki sifat multilingual multi-dimensional, dan multi- pengembangan. Kaitannya dengan apa yang telah disampaikan oleh Ening Widaningsih bahwa pembelajaran seni budaya dan prakarya di lingkungan Sekolah Dasar memiliki sifat yang mengandung mengetahui, memahami, evaluasi memadukan unsur estetika, anak mampu dan dapat mengekspresikan sesuatu dengan unsur bunyi, bahasa rupa, gerak (tari), berperan dan selain itupun anak diberitahukan untuk menumbuhkembangkan kesadaran terhadap beragam budaya nusantara dan mancanegara.

Melihat betapa pentingnya pembelajaran sehingga perlu diterapkan dibeberapa tempat ketika anak tumbuh di lingkungan, dan tentu hal ini tetap dalam ranah membelajaran yang positif dan tetap dalam pantauan guru serta orang tua. Pada masa pademi saat ini pembelajaran dapat terlaksana dengan baik dengan menggunakan pembelajaran daring, bahkan di seluruh lapisan pendidikan di Indonesia menggunkan pembelajaran daring dengan hal ini pembelajaran tetap berjalan dan peserta didik tetap dalam pantauan guru ataupun pendidik. Berdasarkan uraian di atas, terdapat dua rumusan masalah dalam penelitian pembelajaran SBdP dimasa pademi saat ini, berikut diantaranya 1) Bagaimanakah proses pembelajaran PAI pada masa pademi? dan 2) Bagaimanakah cara guru memberikan pembelajaran PAI secara daring? Sesuai dengan rumusan masalah maka adapun tujuan yang dimaksud yaitu: 1) Untuk mengetahui proses pembelajaran SBdP dimasa pademi, dan 2) Mengetahui cara guru memberikan materi pembelajaran dimasa pademi saat ini secara daring.

\section{METODE PENELITIAN}

Penelitian ini menggunakan metode deskritif kualitatif yang bertujuan untuk mendeskripsikan kegiatan siswa sekolah dasar dalam proses belajar dimasa pademi Covid-19. Bahan penelitian merupakan mata pelajaran PAI. Subjek dalam penelitian ini adalah guru serta siswa Sekolah Dasar di beberapa wilayah Tarumajaya dan beberapa Sekolah Dasar di wilayah Tarumajaya guna mendapatkan hasil penelitian yang diharap terkait proses pembelajaran daring dimasa pademi saat ini. Teknik pengumpulan data menggunakan teknik triangulasi yaitu observasi, wawancara dan dokumentasi hasil pencapaian karya yang telah ditulis. Observasi penelitian dengan mengumpulkan data-data berupa jurnal yang relevan dengan penelitian penulis serta hasil observasi yang dilakukan dengan melakukan tanya jawab baik berjumpa dan menggunakan pesan whatsapp atau telepon dengan guru serta siswa Sekolah Dasar. Wawancara dilakukan dengan menggunakan video call, telepon, pesan whatshapp serta diskusi dengan beberapa guru Sekolah Dasar terutama guru kelas menggunakan virtual zoom. Dokumentasi yang didapatkan berbentuk hasil observasi dan wawancara sehingga dokumentasi akan dideskrispikan pada hasil dan pembahasan.

\section{HASIL DAN PEMBAHASAN}

Terkait pembelajaran saat ini, pada umumnya menggunakan sistem pembelajaran jarak jauh yang dimana para peserta didik diberikan materi ataupun pekerjaan rumah dengan menggunakan media komputer maupun handphone. Setiap sekolah tentu memiliki kebijkan serta program yang berbeda-beda antara sekolah yang sat dengan sekolah yang lain. Adapun di kota besar hampir keseluruhan pembelajaran daring menggunkan Zoom Meeting, Google Meet, Google Classroom dan masih banyak lainnya. Sedangkan pada umumnya dari hasil observasi terkait pembelajaran daring pada lingkungan wilayah pedesaan hampir keseluruhan hanya menggunakan media pembelajaran dengan Whatsaap. Hal ini memiliki alasan tersendiri bahwa hampir kebanyakan guru serta orang tua murid tidak terlalu banyak tahu ataupun tidak terlalu memahami cara menggunakan IT sehingga lebih memilih aplikasi yang dianggap mudah dan lebih hemat serta jarang ada kendala jaringan dengan menggunakan aplikasi Whatsaap, pada umumnya guru membuat grup kelas dengan memasukan nomor Handphone orangtua murid untuk mempermudah pembelajaran berlangsung guru 
meminta orang tua tetap mendampingi siswa dalam kegiatan proses belajar dengan alasan jika siswa tidak paham dengan apa yang disampaikan guru, orang tua dapat membantu anaknya memberikan bimbingan belajar di rumah. Guru pun memberikan materi pembelajaran di setiap pertemuan, tanya jawab, pemberian tugas, dan pengumpulan tugas, tentu hal ini perlu adanya kesadaran orang tua untuk tetap membimbing dan memantau anaknya agar tidak malas untuk belajar dimasa pademi.

Aspek yang mencangkup pada pembelajaran PAI memiliki nilai mengandung unsur seni dimana pada umumnya dilihat pada pola pikir yang memiliki nilai ekstetika dan suatu keindahan. Ketika siswa mengikuti kegiatan belajar pelajaran PAI perlu menggunakan empat faktor diantaranya berimajinasi, kreativitas, karya dan produksi. Dimasa pademi saat ini tentu seorang pendidik, orang tua dan peserta didik dituntut untuk banyak belajar di rumah karena proses pembelajaran di sekolah untuk sementara tidak tersedia. Menanggapi hal ini tentu peserta didik perlu adanya kepedulian untuk belajar sendiri misal dengan rajin membaca buku akan membuka peluang pengetahuan baru pada bidang tertentu sehingga ada ilmu yang didapat walau tidak hanya di lingkungaan sekolah. Berimajinasi pada pembelajaran PAI merupakan imajinasi yang mendorong anak untuk berpikir luas misal anak diberikan pemahaman untuk membuat Finger Painting berikan cat dan juga kertas gambar dengan memberikan kesempatan siswa untuk menuangkan apa yang akan ia gambar sehingga hal ini terlihat apa yang ia bayangkan untuk masuk ke dunia imajinasi.

Kreativitas pada pembelajaran SBdP tentu sangatlah penting untuk kemajuan pertumbuhan otak siswa dengan yang memiliki motivasi tinggi tentu memiliki semangat untuk berpikir sehingga produktifitas yang didapat akan mendukung siswa untuk menciptakan hal baru misal menemukan gerakan pada tari kreasi. Karya dan produksi pada pembelajaran PAI tentu memiliki raung sendiri dimana siswa akan bangga untuk diberikan kesempatan untuk berkarya tentu akan senang jika karyaa tersebut dapat diproduksi dengan nilai jual, misal siswa membuat dompet menggunakan anyaman. Pada umumnya pembelajaran PAI merupakan pembelajaran praktik sehingga perlu adanya kreativitas guru dalam pemberikan materi dan menyiapkan media pembelajaran. Dimasa pademi saat ini tentu diperlukan membuat tutorial video bahan ajar misal membuat prakarya anyaman guru memberikan pelatihan berbentuk video dan dishare pada siswa.

Pembelajaran PAI dimasa pademi saat ini memang terasa sangat sulit jika melaksanakan kegiatan belajar secara praktik dimana keterbatasan kuota dan jaringan yang kurang mewadahi sehingga hal ini yang menjadi faktor utama kesulitan dalam pemberian materi praktik. Dari pengakuan salah satu seorang guru menjelaskan bahwa selama pademi mengalami kesulitan pada pemberian materi kepada siswa hal ini perlu adanya bantuan dari orangtua murid, pada masa pademi guru hanya memberikan materi SBdP menggunakan Whatsaap maupun Youtube (siswa diberikan tugas melihat materi praktik di Youtube). Agar pembelajaran PAI berjalan seperti yang diharapkan maka perlu adanya kesadaran guru untuk membuat video praktik misal menggunkan rekaman video yang dikirim melalui Whatsapp atau menggunakan channel Youtube.

Cara mudah agar siswa tertarik belajar PAI dimasa pademi saat ini adalah dengan menyiapkan dulu rancangan materi, seni apa yang akan diberikan: 1) pilih materi yang menarik, dalam hal ini perlu adanya pilihan materi yang menarik misal guru memberikan contoh pembuatan mozaik dengan menggunakan bahan alam misal biji-bijian jagung, kacang hijau atau beras, lalu lakukan tutorial cara membuat burung menggunakan biji-bijian yang sudah disiapkan, 2) siapkan berbagai bahan atau alat untuk praktik, misal guru akan memberikan materi melatih gerak dasar tari Jawa Tengah alat yang diperlukan adalah jarit, benting dan sampur, lalu guru membuat contoh gerakan dasar tari dengan membuat video atau menggunakan Virtual Zoom, 3) luangkan waktu untuk belajar bersama, jika waktunya memenuhi membuat jadwal diluar jadwal sekolah misal melakukan pelatihan bertatap muka minimal dengan 5 anak untuk praktek salat Dhuha, dengan harapan siswa dan guru tetap menggunakan protokol kesehatan yang telah ditentukan oleh pemerintah, 4) diskusi dengan orang tua murid, pembelajaran yang diberikan guru kepada siswa selama pembelajaran daring perlu adanya obrolan khususu dengan orang tua murid, hal ini agar pembelajaran dapat mudah dan terarah semisal anak kesulitan dalam menangkap materi yang telah disampaikan guru, didampingi belajar online sehingga anak paham cara menggunakan aplikasi yang tersedia.

Keseluruhan bidang seni mempelajari materi dengan praktik sehingga sangat sedikit teori 
yang disampaikan dalam hal ini siswa memiliki peluang yang banyak untuk memanfaatkan fasilitas berupa bahan berkarya, imajinasi, produktivitas dan juga nilai. Dalam kondisi pademi saat ini tentu pembelajaran pada umumnya menggunakan daring sehingga untuk memudahkan guru dan murid dalam kegiatan belajar mengajar di rumah sehingga perlu adanya kedisiplinan waktu dapat menghemat waktu yang ada dengan mengikuti belajar dengan tertib di rumah. Melihat hal ini tentu pemahaman kita tertuju pada kenyataan bahwa dengan kondisi teknologi saat ini yang telah maju sehingga perlu memanfaatkan teknologi yang ada. Tentu dalam wilayah perkotaan kemungkinan keseluruhan sekolah menggunakan pembelajaran daring karena tidak kesulitan dalam menemukan jaringan dan kuota yang memadai, bandingkan dengan daerah pedesaan ataupun pedalaman betapa sulitnya mencari jaringan dan bahkan mencari uang untuk dapat membeli kuota. Dalam penelitian yang telah dilakukan penulis menemukan suatu tanggapan bahwa ada beberapa sekolah yang mengalami banyak kesulitan terkait tidak memiliki handphone ataupun laptop sehingga hal ini menjadi kendala dalam kegiatan belajar, adapun temuan bahwa sebagian siswa meminjam handphone temannya untuk memberikan laporan pekerjaan rumah (PR), hal ini sungguh memprihatinkan dan juga perlu adanya apresiasi pihak sekolah untuk dapat mencari solusi yang dialami oleh peserta didik.

Adapun penemuan dari hasil observasi dan wawancara dengan wali murid siswa kelas 1,2,3, beranggapan bahwa siswa tersebut selama sekolah daring diberikan tugas pada mata pelajaarn PAI ada bebwrapa kendala yang di alami. Ada apa pada pembelajaran PAI dimasa pademi saat ini, dari pengakuan siswa dari berbagai kelas dan berbagai sekolah telah memberikan jawaban yang serentak sehingga perlu adanya kesadaran bagi para pendidik. Pembelajaran PAI merupakan pembelajaran praktik yang pada umumnya dikerjakan secara berkelompok ataupun tugas individu, jika pembelajaran daring diberikan pada pademi saat ini tentu berbeda dalam pemberian tugas kepada siswa dibanding dengan pembelajaran tatap muka di kelas. Diambil pada contoh dalam pemberian materi pada PAI, pemberian materi pada pembelajaran PAI pada masa pademi saat ini dapat dibagi menjadi dua bagian yaitu dapat berbentuk pembelajaran manual dan juga pembelajaran online. a) Metode rancangan pembelajaran manual:

1. Guru datang ke rumah siswa memberikan arahan dan memberikan arahan membaca niat sebelum dan sesudah wudhu

2. cara mengambil wudhu yang benar,

3. guru memberikan arahan tentang gerakan-gerakan salat, serta bacaanbacaan salat,

4. Praktik yang di dampingi guru.

5. Dokumentasi Terlampir

b) Metode pembelajaran online pun sama terlebih dahulu membuat rancangan, selanjutnya;

1. guru menghubungi orangtua murid untuk mengunakan akun Zoom, Google Classroom atau Whatsapp pada saat pembelajaran,

2. guru menjelaskan dan menyiapkan video pembelajaran yang di kuirimkan via Chanal Youtube,

3. guru memberikan arahan selama kegiatan PJJ Berlangsung,

4. siswa mengamati dan praktik.

\section{SIMPULAN}

Sesuai dengan pembahasan di atas maka dapat ditarik kesimpulan sebagai berikut: 1) proses pembelajaran PAI memiliki banyak kendala baik terkait jaringan maupun kuota sehingga siswa perlu meminjam handphone agar dapat mengikuti pembelajaran dan mengumpulkan tugas kepada guru; 2) orang tua murid ikut andil membantu proses belajar secara daring, 3) adanya diskusi dan kerjasama dengan orang tua murid agar pembelajaran dapat berjalan dengan lancar, 4) pembelajaran PAI dimasa pademi guru memberikan tugas dengan menggunakan aplikasi Whatsaap dan memberikan contoh materi menggunakan Youtube, 5) pembelajaran PAI menggunakan dua metode pembelajaran yaitu dengan pembelajaran offline dan online.

Dari uraian pada kesimpulan di atas maka dapat dipahami bahwa betapa pentingnya pelajaran PAI pada masa pademi saat ini, guru .m,menggunakan media pembelajaran PAI dengan memanfaatkan teknologi berupa aplikasi Whatsapp, dan Youtube. Adapun dari sebagian siswa yang telah diwawancarai bahwa dari mereka mengalami kendala ketika PJJ materi PAI. Materi PAI ketika praktik dapat dilaksanakan dengan menggunakan pembelajaran secara offline maupun online 


\section{DAFTAR RUJUKAN}

Arsyad, Azhar. 2017. Media Pembelajaran. Jakarta: PT. Rajagrafindo Persada.

Arbaiyah, Mareta Noer Chabiba. 2018. Integrasi Muatan Karakter melalui Pembelajaran SBdP di SDN Jajartunggal III/452 Surabaya. Jurnal Penelitian Guru Sekolah Dasar. Vol 6 (2).

Efendi, Albert. 2020. Konsep Pembelajaran Daring Berbasis Pendekatan Ilmiah. Grobongan Jawa Tengah: CV Sarnu Untung.

Lodo. N.S.A. 2017. Analisis Sikap dan Muatan Pembelajaran SBdP pada Tema Lingkungan Sahabat Kita Kurikulum 2013 Kelas V serta Potensi Budaya Lokal Pendukung dalam Pembelajaran. Jurnal Ilmi

Ni Komang Suni Astin. 2020. Pemanfaatan Teknologi Informasi dalam Pembelajaran
Tingkat Sekolah Dasar pada Masa Pandemi Covid-19. Jurnal Lampuhyang Lembaga Penjaminan Mutu STKIP Agama Hindu Amlapura, Vol. 1(1), Nomor 2 Juli 2020, ISSN: 2087-0760.

Pekerti. Widia, Dkk. 2018. Metode Pengembangan Seni. Banten: Universitas Terbuka.

Sarinah. 2019. Ilmu Sosial Budaya Dasar. Deepublish.

Suardi.Moh. 2018. Belajar dan Pembelajaran. Yogyakarta: Deepublish CV Budi Utama.

Widaningsih. Ening. 2020. Pembelajaran Seni Budaya dan Keterampilan Menumbuhkan Kecerdasan Moral secara Kompetitif. EduHumaniora: Jurnal Pendidikan Dasar. Diterbitkan atas kerjasama Program Studi PGSD UPI Kampus Cibiru dan HDPGSD 